\title{
Penerapan TGT-Chempuzzle pada Pembelajaran Hidrokarbon untuk Meningkatkan Prestasi Belajar Kimia Peserta Didik
}

\author{
Yuliyanti Hana Pertiwi ${ }^{1}$ *, Mohammad Masykuri ${ }^{1}$ \\ ${ }^{1}$ Program Studi Pendidikan Kimia, Fakultas Keguruan dan Ilmu Pendidikan, Universitas Sebelas \\ Maret. Jalan Ir. Sutami 36 A, Surakarta, 57126, Indonesia \\ * Corresponding Author. Email: yuliyantihp@gmail.com
}

Received: 13 October 2016; Revised: 17 February 2017; Accepted: 10 April 2017

\begin{abstract}
Abstrak
Penelitian ini bertujuan untuk meningkatkan prestasi belajar kimia peserta didik pada pembelajaran hidrokarbon dengan penerapan model pembelajaran Teams Games Tournament (TGT) menggunakan Chempuzzle. Penelitian ini merupakan Penelitian Tindakan Kelas yang terdiri atas dua siklus. Setiap siklus terdiri atas tahap perencanaan, pelaksanaan, observasi, dan refleksi. Pada siklus I diterapkan model pembelajaran Teams Games Tournament (TGT) menggunakan Chempuzzle pada materi hidrokarbon, sedangkan siklus II diterapkan model pembelajaran yang sama tetapi hanya pada indikator materi yang belum tuntas pada siklus I. Teknik pengumpulan data diperoleh melalui wawancara, observasi, angket, dan tes. Teknik analisis data yang digunakan adalah analisis deskriptif kualitatif. Hasil penelitian menunjukkan bahwa penerapan model pembelajaran Teams Games Tournament (TGT) menggunakan Chempuzzle dapat meningkatkan prestasi belajar kimia peserta didik pada pembelajaran hidrokarbon. Peningkatan prestasi belajar aspek kognitif meningkat dari 42,9\% pada siklus I menjadi $77,1 \%$ pada siklus II. Persentase aspek afektif pada siklus I adalah $100 \%$, sehingga pada siklus II tidak dilanjutkan karena semua indikator sudah tercapai.
\end{abstract}

Kata Kunci: Teams Games Tournament (TGT), chempuzzle, hidrokarbon, prestasi belajar

\section{The Implementation TGT-Chempuzzle of Hydrocarbon to Improve Student's Chemistry Learning Achievement}

\begin{abstract}
This research aims to improve student's chemistry learning achievement of Hydrocarbon with the implementation of Teams Games Tournament (TGT) learning model using Chempuzzle. This research was a Classrom Action Research which consist two cycles. Each cycles consist of planning, action, observation, dan reflection phases. Both use Teams Games Tournament (TGT) learning model using Chempuzzle in hydrocarbon material, but on the second cycle only use unfinished indicators in the first cycle. Data were collected through interview, observation, questionnaire, and test. Data were analyzed by technique of qualitative descriptive. The result of the research showed that the implementation of Teams Games Tournament (TGT) learning model using Chempuzzle could improve student's chemistry learning achievement of hydrocarbon. The improvement of student's learning achievement cognitive aspect increase from $42,9 \%$ in the first cycle to $77,1 \%$ in the second cycle. The affective aspect percentage in the first cycle was $100 \%$, so the second cycle is discontinued because all indicators have been achieved.
\end{abstract}

Keywords: Teams Games Tournament (TGT), chempuzzle, hydrocarbon, learning achievement

How to Cite: Pertiwi, Y., \& Masykuri, M. (2017). Penerapan TGT-Chempuzzle pada pembelajaran hidrokarbon untuk meningkatkan prestasi belajar kimia peserta didik. Jurnal Inovasi Pendidikan IPA, 3(1), 111-117. doi:http://dx.doi.org/10.21831/jipi.v3i1.11198

Permalink/DOI: http://dx.doi.org/10.21831/jipi.v3i1.11198 


\section{Jurnal Inovasi Pendidikan IPA, 3 (1), 2017 - 112}

Yuliyanti Hana Pertiwi, Mohammad Masykuri

\section{PENDAHULUAN}

Pendidikan merupakan salah satu hal yang sangat penting bagi manusia. Berdasarkan Undang-Undang Republik Indonesia Nomor 20 Tahun 2003 tentang Sistem Pendidikan Nasional, tujuan pendidikan adalah mengembangkan kemampuan dan membentuk watak serta peradaban bangsa yang bermartabat dalam rangka mencerdaskan kehidupan bangsa. Bangsa yang maju adalah bangsa yang mempunyai sumber daya manusia yang berkualitas. Untuk menghasilkan sumber daya manusia yang berkualitas diperlukan sistem pendidikan yang berkualitas pula, sehingga kualitas pendidikan harus dijaga dan ditingkatkan (Presiden Republik Indonesia, 2003).

Salah satu usaha yang dilakukan pemerintah untuk memperbaiki kualitas pendidikan di Indonesia adalah pembaharuan kurikulum secara berkesinambungan (Anitah, 2009, p. 31). Kurikulum yang sedang dikembangkan di Indonesia adalah kurikulum 2013, yang merupakan perbaikan dari kurikulum sebelumnya yaitu Kurikulum Tingkat Satuan Pendidikan (KTSP). Pemberlakuan kurikulum 2013 dilakukan secara bertahap, sehingga masih terdapat beberapa sekolah yang belum menerapkan kurikulum tersebut. Salah satu sekolah yang belum menerapkan kurikulum 2013 adalah SMA Negeri 2 Boyolali. Kurikulum yang diterapkan di SMA tersebut adalah Kurikulum Tingkat Satuan Pendidikan (KTSP).

KTSP adalah kurikulum operasional yang pengembangannya diserahkan pada masingmasing daerah dan satuan pendidikan (Mulyasa, 2007, p. 20). Berdasarkan Permendiknas Nomor 22 Tahun 2006, pelaksanaan kurikulum didasarkan pada potensi, perkembangan, dan kondisi peserta didik untuk menguasai kompetensi yang berguna bagi dirinya. Dalam hal ini peserta didik harus mendapatkan pelayanan pendidikan yang bermutu, serta memperoleh kesempatan untuk mengekspresikan dirinya secara bebas, dinamis, dan menyenangkan. Kurikulum ini tidak lagi menggunakan pendekatan yang didominasi oleh guru, tetapi siswa juga harus lebih aktif selama proses pembelajaran. Penggunaan model dan media pembelajaran yang kreatif, interaktif, dan menarik akan membantu siswa mencapai tujuan pembelajaran (Sumantri, 2001, p. 150). Menurut Mulyasa (2007), mata pelajaran kimia bertujuan agar siswa memiliki kemampuan memahami konsep, prinsip, hukum, dan teori kimia serta saling keterkaitannya dan penerapannya untuk menyelesaikan masalah dalam kehidupan sehari-hari. Ketercapaian tujuan pembelajaran sangat dipengaruhi oleh beberapa faktor misalnya model dan media pembelajaran. Penggunaan model dan media pembelajaran dapat membantu keterbatasan guru dalam menyampaikan pelajaran.

Berdasarkan wawancara dengan guru kimia Kelas X SMA Negeri 2 Boyolali, salah satu materi kimia kelas $\mathrm{X}$ yang dianggap sulit oleh siswa adalah materi hidrokarbon. SMA Negeri 2 Boyolali menetapkan Kriteria Ketuntasan Minimal (KKM) untuk mata pelajaran kimia pada tahun pelajaran 2014/2015 yakni 75 . Nilai rata-rata kimia pada materi hidrokarbon siswa kelas X SMA Negeri 2 Boyolali Tahun Pelajaran 2014/2015 dapat dilihat pada Tabel 1.

Tabel 1. Nilai Rata-rata Ulangan Harian Materi Hidrokarbon Kelas X SMA Negeri 2 Boyolali Tahun Pelajaran 2014/2015

\begin{tabular}{ccc}
\hline Kelas & Rata-rata nilai & $\begin{array}{c}\text { Persentase ketuntasan } \\
(\%)\end{array}$ \\
\hline X1 & 67,4 & 27,3 \\
X2 & 67,1 & 9,1 \\
X3 & 72,4 & 50,0 \\
X4 & 73,3 & 54,5 \\
X5 & 69,4 & 27,9 \\
X6 & 69,0 & 23,3 \\
X7 & 74,0 & 48,5 \\
X8 & 70,3 & 36,7 \\
\hline \multicolumn{2}{c}{ Berdasarkan Tabel 1 dapat dilihat nilai }
\end{tabular}
rata-rata kelas dan persentase ketuntasan materi hidrokarbon pada masing-masing kelas. Ratarata persentase ketuntasan siswa yang mencapai KKM pada materi hidrokarbon tahun pelajaran 2014/2015 hanya $34,7 \%$. Banyaknya siswa yang memiliki nilai belum mencapai KKM merupakan salah satu indikasi masalah pada materi yang diberikan.

Dalam penelitian ini peneliti memilih kelas X8 sebagai kelas yang diperbaiki karena didasarkan pada prestasi belajar kelas X pada Ulangan Akhir Semester ganjil tahun pelajaran 2015/2016 yang tergolong rendah dibanding kelas yang lain. Berdasarkan hasil observasi yang dilaksanakan pada tanggal 12 Januari 2016 didapatkan bahwa kelas X8 merupakan kelas yang tergolong kurang aktif selama pembelajaran.

Berdasarkan permasalahan yang ada maka diperlukan suatu tindakan untuk dapat meningkatkan prestasi belajar siswa. Tindakan ini dapat dilakukan melalui sebuah Penelitian Tindakan Kelas (PTK) yang memiliki tujuan untuk mengadakan perbaikan atau peningkatan mutu praktik pembelajaran di kelas. Salah satu upaya 
yang dapat dilakukan adalah dengan menerapkan model pembelajaran kooperatif, dimana proses pembelajaran tidak hanya berpusat pada guru namun siswa juga dituntut untuk aktif dan memperhatikan temannya untuk dapat berkompetisi dengan kelompok lain sehingga menciptakan suasana pembelajaran yang positif. Model pembelajaran kooperatif yang melibatkan siswa dalam kelompok dapat membantu siswa dalam memahami konsep dan teori pada materi senyawa hidrokarbon. Salah satu model pembelajaran yang dapat diterapkan adalah model pembelajaran Teams Games Tournament (TGT), karena dengan $T G T$ siswa menjadi lebih aktif dalam proses pembelajaran. Situasi pembelajaran juga menjadi lebih menyenangkan dengan adanya suatu permainan. Hal ini diharapkan agar siswa lebih mudah memahami materi yang disampaikan oleh guru. Sebuah penelitian menyebutkan bahwa model pembelajaran TGT dapat meningkatkan prestasi dan sikap yang baik dalam pembelajaran ekonomi (van Wyk, 2011). Model pembelajaran TGT juga dapat mengembangkan perilaku positif siswa khususnya dalam memecahkan masalah yang kompleks (Veloo \& Chairhany, 2013).

Model pembelajaran yang digunakan dalam proses pembelajaran akan lebih berhasil apabila disertai dengan media (Sagala, 2010). Penggunaan media ini dapat menumbuhkan interaksi antara guru dan siswa sehingga pembelajaran bisa berlangsung lebih efektif dan efisien. Salah satu media pembelajaran yang dapat dipadukan dengan model pembelajaran TGT adalah media pembelajaran Chempuzzle. Pada penelitian yang dilakukan oleh Nuraeni (2015), media Chempuzzle ini dinilai efektif untuk meningkatkan kreativitas siswa.

Puzzle merupakan potongan-potongan gambar, angka, maupun huruf yang memiliki pasangan satu sama lain dan akan menghasilkan bentuk tertentu (Muljo, 2013; Rahmanelli, 2008). Berdasarkan penelitian sebelumnya menyebutkan bahwa ada interaksi antara penggunaan media puzzle terhadap prestasi kognitif siswa (Khudori, Ashadi, \& Masykuri, 2012, p. 156). Media Chempuzzle dalam penelitian ini terdiri atas potongan-potongan gugus fungsi dan katakata. Chempuzzle yang disesuaikan dengan materi hidrokarbon ini dapat melatih siswa memecahkan soal yang diberikan dengan merangkai potongan gugus fungsi dan kata-kata yang merupakan jawaban dari soal yang diberikan, sehingga nantinya dapat meningkatkan prestasi belajar siswa.
Penelitian ini menerapkan model pembelajaran Teams Games Tournament (TGT) menggunakan Chempuzzle pada pembelajaran hidrokarbon. Tujuan dari penelitian ini adalah untuk meningkatkan prestasi belajar kimia peserta didik dengan penerapan TGT-Chempuzzle pada pembelajaran hidrokarbon.

\section{METODE}

Penelitian ini merupakan Penelitian Tindakan Kelas yang terdiri atas dua siklus. Setiap siklus terdiri atas tahap perencanaan, pelaksanaan, observasi, dan refleksi. Pada siklus I tahapan penelitian dilakukan pada semua indikator materi hidrokarbon, sedangkan siklus II hanya pada indikator materi siklus I yang belum tuntas.

Waktu penelitian dimulai pada bulan Januari hingga Mei 2016. Penelitian ini dilakukan di SMA Negeri 2 Boyolali, yang beralamat di jalan Tentara Pelajar Nomor 06, Kebonbimo, Boyolali.

Subjek penelitian ini adalah siswa kelas X8 yang berjumlah 35 siswa. Pemilihan subjek didasarkan pada pertimbangan bahwa subjek tersebut mempunyai permasalahan-permasalahan yang telah teridentifikasi pada saat observasi awal.

Penelitian ini dilakukan dengan mengikuti model yang dikembangkan oleh Kemmis dan Mc Taggart. Langkah yang dilakukan dalam penelitian ini yaitu perencanaan tindakan (planning), tindakan (acting), pengamatan (observing), dan refleksi (reflecting). Kegiatan ini disebut dengan satu siklus kegiatan pemecahan masalah (Arikunto, Suhardjono, \& Supardi, 2010, p. 117). Prosedur PTK biasanya meliputi beberapa siklus, sesuai dengan tingkat permasalahan yang dipecahkan dan kondisi yang akan ditingkatkan (Mulyasa, 2012, p. 70).

Pada siklus I, kegiatan perencanaan meliputi observasi untuk mengidentifikasi permasalahan dalam pembelajaran kimia dan menyusun serangkaian pelaksaaan tindakan berupa penggunaan model pembelajaran dan penyusunan instrumen penelitian yang meliputi tes aspek kognitif dan angket untuk aspek afektif siswa, serta media penelitian. Selanjutnya tahap tindakan meliputi pelaksanaan proses belajar mengajar dan penyelenggaraan penilaian. Tahap pengamatan meliputi pencatatan semua hasil pengamatan oleh guru dan peneliti terhadap siswa dan pembuatan kesimpulan hasil pengamatan. Tahap terakhir yaitu refleksi. Pada tahap ini dilakukan pengkajian dan pertimbangan hasilhasil atau dampak dari tindakan. Peneliti dan 


\section{Jurnal Inovasi Pendidikan IPA, 3 (1), 2017 - 114}

Yuliyanti Hana Pertiwi, Mohammad Masykuri

guru berdiskusi untuk mengambil keputusan menentukan tindakan berikutnya (siklus II) pada proses pembelajaran yang dilaksanakan oleh guru.

Pada siklus II, perencanaan tindakan dilaksanakan berdasarkan hasil refleksi siklus I. Materi yang akan diajarkan difokuskan pada indikator kompetensi yang belum tuntas pada siklus I.

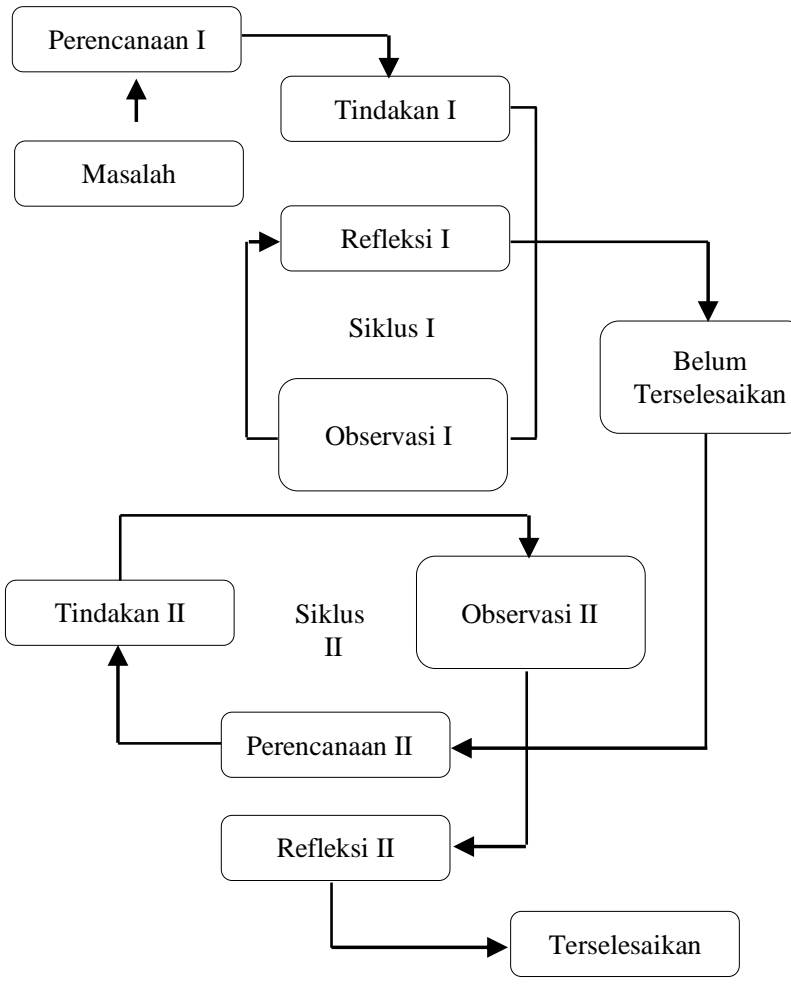

Gambar 1. Prosedur Penelitian

\section{Teknik Pengumpulan Data}

Pengumpulan data dalam penelitian ini dilakukan dengan dua teknik, yaitu tes dan non tes. Tes dilakukan untuk mendapatkan data prestasi belajar aspek kognitif pada pembelajaran hidrokarbon. Dalam penelitian ini, tes kognitif berupa tes objektif (pilihan ganda). Teknik non tes terdiri atas wawancara, observasi, angket, dan dokumentasi.

\section{Teknik Analisis Data}

Teknik analisis data yang digunakan adalah analisis deskriptif kualitatif yang mengacu pada model analisis Miles, Huberman, \& Saldaña (2014), yaitu reduksi data, penyajian data, penarikan kesimpulan, dan verifikasi (Sugiyono, 2010, p. 337).

Data yang diperoleh dari lapangan perlu dilakukan reduksi data. Reduksi data merupakan

Merangkum hal-hal yang pokok dan penting, dan membuang hal yang tidak perlu.
Dengan demikian data yang telah direduksi akan memberikan gambaran yang lebih jelas sehingga mempermudah peneliti untuk mengumpulkan data selanjutnya.

Setelah reduksi data maka langkah selanjutnya adalah penyajian data. Penyajian data dilakukan untuk mengorganisasikan data yang merupakan panyusunan informasi secara sistematik dari hasil reduksi data yang dimulai dari perencanaan, pelaksanaan tindakan, observasi, dan refleksi pada masing-masing siklus.

Tahap terakhir yaitu penarikan kesimpulan dan verifikasi. Penarikan kesimpulan merupakan upaya pencarian makna data, mencatat keteraturan dan penggolongan data. Selanjutnya untuk mempermudah verifikasi dan analisis, data yang diperlukan untuk menjawab permasalahan yang ada diidentifikasi secara khusus pada tiap-tiap siklus pembelajaran. Untuk menjaga kevalidan data dalam penelitian digunakan teknik triangulasi, yaitu teknik pemeriksaan data untuk keperluan pengecekan atau sebagai pembanding terhadap data. Teknik triangulasi dilakukan dengan mengumpulkan data tetap dengan metode pengumpulan data yang berbeda-beda. Pada penelitian ini pengumpulan data melalui observasi, wawancara, dan angket belajar siswa.

\section{HASIL DAN PEMBAHASAN}

\section{Siklus I}

Pada tahap perencanaan siklus I, peneliti dan guru melakukan kajian kembali terhadap silabus yang telah dibuat oleh guru sesuai dengan kondisi dan kebutuhan sekolah. Silabus dari sekolah ini dimodifikasi oleh peneliti sehingga sesuai dengan model pembelajaran yang akan diterapkan. Berdasarkan silabus ini peneliti membuat Rencana Pelaksanaan Pembelajaran (RPP) yang terdiri atas empat kali pertemuan yang terdiri atas tiga kali pertemuan (6 x 45 menit) untuk proses pembelajaran dan satu kali pertemuan (2 x 45 menit) untuk penilaian. Peneliti juga menyiapkan media pembelajaran berupa Chempuzzle yang merupakan potonganpotongan kertas yang isinya berkaitan dengan materi hidrokarbon. Selanjutnya peneliti menyiapkan instrumen penilaian yang meliputi penilaian aspek kognitif dan afektif. Instrumen lain yang harus disiapkan adalah lembar observasi untuk menilai sikap siswa selama proses pembelajaran yang disesuaikan dengan kisi-kisi dan indikator penilaian afektif.

Pelaksanaan tindakan pada siklus I dilaksanakan berdasarkan Rencana Pelaksanaan 


\section{Jurnal Inovasi Pendidikan IPA, 3 (1), 2017 - 115}

Yuliyanti Hana Pertiwi, Mohammad Masykuri

Pembelajaran (RPP) yang sudah dibuat. Pelaksanaan siklus I diawali dengan pemberian pengarahan mengenai model TGT yang diterapkan pada materi hidrokarbon dan pembentukan kelompok oleh guru, setelah itu siswa duduk sesuai dengan kelompoknya. Setiap kelompok terdiri atas 5-6 siswa yang didalamnya terdiri atas siswa yang memiliki prestasi belajar dan jenis kelamin yang berbeda. Pembentukan kelompok ini bertujuan agar siswa dapat bekerja sama untuk memecahkan masalah dan saling membantu apabila ada anggota kelompoknya yang belum memahami materi pelajaran. Pembentukan kelompok adalah salah satu tahapan dalam model pembelajaran TGT yaitu teams yang sebelumnya diawali dengan penjelasan singkat oleh guru mengenai materi pelajaran (class presentation). Tahapan selanjutnya adalah permainan (games) dengan menggunakan media pembelajaran Chempuzzle, kemudian di akhir pembelajaran siklus I dilakukan sebuah pertandingan (tournament) dan pengakuan kelompok (teams recognition) berupa pemberian penghargaan kepada kelompok yang dianggap terbaik selama proses pembelajaran pada siklus I. Pada akhir siklus dilakukan penilaian berupa tes aspek kognitif dan afektif.

Berdasarkan hasil analisis tes aspek kognitif didapatkan bahwa jumlah siswa yang telah mencapai batas tuntas (KKM) sebanyak 42,9\%. Persentase ini belum mencapai target yang ditentukan yaitu sebesar $75,0 \%$ siswa tuntas. Sedangkan hasil tes aspek afektif siswa pada siklus I didapatkan persentase afektif siswa kategori baik sebesar 100\%. Penilaian aspek afektif ini terdiri atas lima aspek yaitu sikap, minat, konsep diri, nilai, dan moral. Pada penilaian afektif digunakan teknik triangulasi untuk pengumpulan data yaitu dengan observasi, angket afektif, dan wawancara. Observasi dilakukan selama proses pembelajaran yang diisi oleh observer. Ketercapaian keberhasilan aspek kognitif dan afektif pada siklus I dapat dilihat pada Tabel 2.

Tabel 2. Ketercapaian Target Siklus I

\begin{tabular}{cccc}
\hline \multirow{2}{*}{$\begin{array}{c}\text { Aspek yang } \\
\text { dinilai }\end{array}$} & \multicolumn{2}{c}{ Siklus I } & \\
\cline { 2 - 3 } & $\begin{array}{c}\text { Capaian } \\
(\boldsymbol{\%})\end{array}$ & $\begin{array}{c}\text { Target } \\
(\boldsymbol{\%})\end{array}$ & Kriteria \\
\hline Kognitif & 42,9 & 75,0 & Belum \\
Afektif & 100,0 & 75,0 & Tercapai \\
\hline
\end{tabular}

Berdasarkan Tabel 2. dapat dilihat bahwa aspek afektif sudah mencapai target yang ditentukan, sedangkan pada aspek kognitif siswa belum mencapai target sehingga perlu dilakukan perbaikan pada siklus II. Belum tercapainya target ini dikarenakan masih terdapat beberapa siswa yang belum aktif dalam berdiskusi, kurangnya latihan soal dan pemberian tugas yang diberikan oleh guru. Apabila ditinjau dari ketercapaian setiap indikator kompetensi, diperoleh hasil bahwa terdapat dua indikator yang belum tuntas yaitu pada sub bab menentukan isomer kerangka, posisi, dan geometri (cis dan trans), dan menuliskan reaksi sederhana pada senyawa alkana, alkena, dan alkuna (reaksi oksidasi, reaksi adisi, reaksi substitusi, dan reaksi eliminasi). Oleh sebab itu pada siklus I perlu dilakukan perbaikan pembelajaran yaitu dengan melanjutkan ke siklus II agar target aspek kognitif dapat terpenuhi. Pada siklus II ini materi lebih ditekankan pada indikator kompetensi yang belum tuntas agar dapat mencapai target yang telah ditentukan. Upaya yang dapat dilakukan untuk meningkatkan ketuntasan pada sub bab isomer dan reaksi-reaksi pada senyawa hidrokarbon adalah dengan cara memberikan catatan tambahan dan soal-soal latihan yang bervariasi agar siswa terlatih untuk dapat menyelesaikan soal tentang sub bab tersebut. Pelaksanaan siklus II dilakukan untuk meningkatkan hasil belajar siswa yang belum dicapai pada siklus I.

\section{Siklus II}

Perencanaan tindakan siklus II dilaksanakan berdasarkan hasil refleksi siklus I. Pada siklus II, materi yang diajarkan difokuskan pada indikator kompetensi yang belum tuntas pada siklus I. Tindakan pada siklus II difokuskan untuk perbaikan terhadap kendala-kendala yang terdapat pada siklus I. Proses pembelajaran pada siklus II dilaksanakan dalam dua kali pertemuan, satu kali pertemuan untuk proses pembelajaran dan satu kali pertemuan untuk penilaian. Setelah dilakukan pembelajaran pada siklus II maka dilakukan penilaian untuk aspek kognitif. Tes aspek kognitif berupa soal objektif yang terdiri atas indikator kompetensi yang belum tercapai pada siklus I. Berdasarkan hasil analisis tes aspek kognitif diperoleh siswa yang sudah mencapai KKM sebesar $77,1 \%$, berarti capaian ini sudah memenuhi target yaitu $75,0 \%$. Ketercapaian keberhasilan aspek kognitif pada siklus II dapat dilihat pada Tabel 3. 
Tabel 3. Ketercapaian Target Siklus II

\begin{tabular}{cccc}
\hline \multirow{2}{*}{$\begin{array}{c}\text { Aspek yang } \\
\text { dinilai }\end{array}$} & \multicolumn{2}{c}{ Siklus II } & \\
\cline { 2 - 3 } & $\begin{array}{c}\text { Capaian } \\
(\boldsymbol{\%})\end{array}$ & $\begin{array}{c}\text { Target } \\
\mathbf{( \% )}\end{array}$ & \\
\hline Kogniteria & 77,1 & 75,0 & Tercapai \\
\hline
\end{tabular}

Berdasarkan Tabel 3 dapat diketahui bahwa aspek kognitif sudah mencapai target yang ditentukan. Hasil tes aspek kognitif pada siklus II menunjukkan bahwa kedua indikator kompetensi yang belum tercapai pada siklus I dapat tercapai pada siklus II.

\section{Hasil Antar Siklus}

Penilaian dilakukan pada setiap akhir siklus. Hasil ketuntasan prestasi belajar siswa aspek kognitif pada siklus I dan siklus II dapat dilihat pada Tabel 4.

Tabel 4. Hasil ketuntasan prestasi belajar siswa aspek kognitif pada siklus I dan siklus II

\begin{tabular}{ccc}
\hline \multirow{2}{*}{ Aspek } & \multicolumn{2}{c}{ Persentase (\%) } \\
\cline { 2 - 3 } & Siklus I & Siklus II \\
\hline Kognitif & 42,9 & 77,1 \\
\hline
\end{tabular}

Berdasarkan Tabel 4. dapat diketahui bahwa ketuntasan belajar meningkat dari $42,9 \%$ pada siklus I menjadi $77,1 \%$ pada siklus II. Semua indikator kompetensi pada siklus II telah mencapai target yang sudah ditentukan. Prestasi belajar aspek kognitif dari siklus I ke siklus II berarti terjadi peningkatan sebesar $34,2 \%$. Peningkatan prestasi belajar ini dikhususkan pada indikator kompetensi yang belum tuntas pada siklus I. Terjadinya peningkatan ini dikarenakan penerapan model pembelajaran TGT mampu mendorong siswa untuk lebih aktif dalam kelompok, misalnya siswa akan mendiskusikan dan saling membantu dalam pemecahan masalah pada saat diskusi maupun permainan, sehingga mampu meningkatkan prestasi belajar siswa. Untuk penilaian aspek afektif, sudah didapatkan hasil sebesar $100 \%$ dengan siswa kategori afektif baik sehingga tidak dilanjutkan pada siklus berikutnya.

Materi hidrokarbon merupakan materi yang berisi banyak konsep dan teori yang bersifat abstrak. Penerapan model pembelajaran TGT menggunakan Chempuzzle dapat memberikan suasana yang menyenangkan bagi siswa selama proses pembelajaran misalnya pada saat permainan ataupun turnamen, selain itu dapat memberikan kemudahan siswa untuk memahami pelajaran sehingga mencapai prestasi belajar yang lebih baik. Sejalan dengan penelitian van Wyk (2011) yang mengemukakan bahwa pene- rapan TGT lebih efektif daripada metode ceramah dalam meningkatkan prestasi belajar dan sikap positif siswa terhadap pembelajaran ekonomi.

Berdasarkan hasil penelitian dapat disimpulkan bahwa penelitian ini berhasil karena prestasi belajar yang diukur telah mencapai target yang ditentukan. Hasil yang diperoleh pada siklus II mengalami peningkatan dari siklus I. Dapat ditarik kesimpulan bahwa penerapan TGT-Chempuzzle pada pembelajaran hidrokarbon dapat meningkatkan prestasi belajar kimia peserta didik.

\section{SIMPULAN}

Berdasarkan hasil penelitian yang telah dilakukan, maka dapat diambil kesimpulan bahwa penerapan model pembelajaran Teams Games Tournament (TGT) menggunakan Chempuzzle pada pembelajaran hidrokarbon dapat meningkatkan prestasi belajar kimia peserta didik. Hal ini dapat dilihat dari persentase aspek kognitif pada siklus I sebesar 42,9\% meningkat menjadi $77,1 \%$ pada siklus II. Prestasi belajar afektif pada siklus I adalah $100 \%$.

\section{DAFTAR PUSTAKA}

Anitah, S. (2009). Media pembelajaran. Surakarta: Yuma Pustaka.

Arikunto, S., Suhardjono, \& Supardi. (2010). Penelitian tindakan kelas. Jakarta: Bumi Aksara.

Khudori, M., Ashadi, A., \& Masykuri, M. (2012). Pembelajaran IPA dengan metode TGT menggunakan media games ular tangga dan puzzle ditinjau dari gaya belajar dan kreativitas siswa. Jurnal INKUIRI, 1(2), 154-162. Retrieved from http://jurnal.pasca.uns.ac.id/index.php/ink /article/view/131

Miles, M. B., Huberman, A. M., \& Saldaña, J. (2014). Qualitative data analysis: A methods sourcebook. Los Angeles: Sage.

Muljo, A. (2013). Perkembangan minat belajar siswa tunagrahita embisil (sedang) melalui metode permainan puzzle bangun datar di SMPLB Langsa. In Prosiding (pp. 1-9). Langsa: Sekolah Tinggi Agama Islam Negeri (STAIN) Zawiyah Cot Kala Langsa.

Mulyasa, H. E. (2007). Kurikulum tingkat satuan pendidikan (KTSP). Bandung: PT Remaja Rosdakarya.

Mulyasa, H. E. (2012). Praktik penelitian 


\section{Jurnal Inovasi Pendidikan IPA, 3 (1), 2017 - 117}

Yuliyanti Hana Pertiwi, Mohammad Masykuri

tindakan kelas. Bandung: PT Remaja Rosdakarya. Retrieved from http://rosda.co.id/pendidikankeguruan/419-praktik-penelitiantindakan-kelas.html

Presiden Republik Indonesia. Undang-undang Republik Indonesia Nomor 20 Tahun 2003 tentang sistem pendidikan nasional, Pub. L. No. 20 (2003).

Rahmanelli. (2008). Efektivitas pemberian tugas media puzzle dalam pembelajaran geografi regional. Jurnal Pembelajaran, 30(1), 23-31. Retrieved from http://uilis.unsyiah.ac.id/serial/index.php? $\mathrm{p}=$ show_detail\&id $=8950$

Sagala, S. (2010). Konsep dan makna pembelajaran. Bandung: Alfabeta.

Sugiyono. (2010). Metode penelitian pendidikan: Pendekatan kuantitatif, kualitatif, dan $R \& D$. Bandung: Alfabeta.

Sumantri, M. (2001). Strategi belajar mengajar.
Bandung: CV Maulana.

van Wyk, M. M. (2011). The effects of teamsgames-tournaments on achievement, retention, and attitudes of economics education students. Journal of Social Science, 26(3), 183-193. Retrieved from http://www.krepublishers.com/02Journals/JSS/JSS-26-0-000-11-Web/JSS26-3-000-11-Abst-PDF/JSS-26-3-183-111132-Van-Wyk-M-M/JSS-26-3-183-111132-Van-Wyk -M-M-Tt.pdf

Veloo, A., \& Chairhany, S. (2013). Fostering students' attitudes and achievement in probability using teams-gamestournaments. In 3rd World Conference on Learning, Teaching and Educational Leadership (Vol. 93, pp. 59-64). Procedia - Social and Behavioral Sciences.

http://doi.org/10.1016/j.sbspro.2013.09.15 2 